\title{
Proteus mirabilis Chromosome Mobilization by Plasmid D: a Physical Characterization
}

\author{
By MARTEN C. VAN DIJKEN AND WILLEM F. COETZEE* \\ MRC Unit for Microbial Genetics, University of Pretoria, PO Box 2034, Pretoria 0001, \\ Republic of South Africa
}

(Received 26 July 1983; revised 7 November 1983)

\begin{abstract}
Plasmid D, a hybrid of plasmids P-lac and Rldrd19, mediates polarized chromosome mobilization from one origin in Proteus mirabilis strain PM5006, while the parental plasmids neither individually nor combined mobilize this chromosome. To elucidate its acquired mobilizing ability plasmid D was characterized physically in relation to P-lac and R1drd19. Restriction patterns of these plasmids were compared and it was shown that D consists of P-lac and only the r-determinant ( $\mathrm{r}$-det) of R1drd 19. A mechanism for the formation of plasmid D, via transduction of the $\mathrm{r}$-det and subsequent transposon-like integration into P-lac, involving insertion sequence IS1, was suggested. Evidence for aberration in plasmid D DNA as a result of $r$-det integration into P-lac was attributed to IS1 elements which flank the $r$-det. Recombination regions of parental plasmid DNA were located on HindIII fragments $\alpha$ and $\beta$ of plasmid D and were subsequently inserted in vitro into IncP-1 plasmid RP4 that fails to mobilize the $P$. mirabilis chromosome. RP4:: HindIII $\alpha$ plasmids did not mobilize the latter chromosome, but rendered the Proteus host lac ${ }^{+}$. RP4:: HindIII $\beta$ plasmids pMCl and $\mathrm{pMCl}$, containing the fragment in opposite orientations, mobilized the $P$. mirabilis chromosome. For pMC17, mobilization was indistinguishable from that of plasmid $\mathrm{D}$, i.e. having the same orientation and the same single origin. However, mobilization promoted by $\mathrm{pMCl}$ was from two distinctly different origins, different from that of pMC17. This apparently deviates from known examples where inversion of homologous DNA inserted into plasmids leads to mobilization from the same origin but in reverse direction.
\end{abstract}

\section{INTRODUCTION}

Plasmid D is a hybrid of plasmids P-lac (Wohlhieter et al., 1964) and R1drd19 (Meynell \& Datta, 1967) and was originally named P-lac $\overline{\mathrm{R} 1 d r d 19}$ (Coetzee, 1974). It mediates polarized chromosome mobilization from a single origin in Proteus mirabilis strain PM5006 (Coetzee, 1975). The parental plasmids, although capable of chromosome mobilization in Escherichia coli (Falkow et al., 1964; Pearce \& Meynell, 1968), neither individually nor combined mobilize the chromosome of $P$. mirabilis (Coetzee, 1975).

Plasmid D contains the Tra functions and lac marker of P-lac (Hedges, 1975) and at least the rdeterminant (r-det) of R1drd19, as suggested by genetic evidence (Coetzee, 1974). However, plasmid D has not been physically analysed in terms of the parental plasmids. Except for a molecular mass determination of $101 \mathrm{MDal}$ (Coetzee et al., 1975) P-lac has also not been physically characterized, whereas restriction maps and a molecular mass of $62.5 \mathrm{MDal}$ have been established for R1drd19 (Blohm \& Goebel, 1978; Clerget et al., 1981).

This paper deals with a comparative analysis of plasmids P-lac, R1drd19 and D by restriction fragmentation, with a view to establishing the composition of plasmid $\mathrm{D}$, characterizing the recombination sites of P-lac and R1drd19 in the hybrid, and elucidating its chromosome mobilizing ability (Cma). 
Table 1. Bacterial strains and plasmids

Bacterial strain
Proteus mirabilis
PM5006
UP101
UP102
UP103
UP104
UP105
UP106
UP107
Escherichia coli K12
C600 $\mathrm{r}^{-} \mathrm{m}^{-}$

Relevant properties
Wild-type Tck
his-1 nalAI str-2
trpA nalAI str-2
itv-2 nalAI str-2
pur-I nalAI str-2
cysC nalAI str-2
metF nalAI str-2
argE nalAI str-2
thr-I leuB6 thi-1
hsdSI lac YI tonA2I
$\lambda^{-}$supE 44

Derivation

Reference/Source

J. N. Coetzee

NTG*-induced

mutants of PM5006

J. N. Coetzee

(unpublished)

E. coli Genetic

Stock Centre

Plasmid $\uparrow$

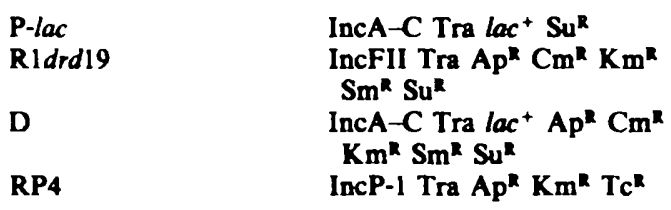

Hedges (1975)

Meynell \& Datta

(1967)

Coetzee (1978)

Datta et al. (1971)

Holloway \&

Richmond (1973)

$\left.\begin{array}{ll}\text { pMC1 } \\ \text { pMC17 } \\ \text { pMC41 } \\ \text { pMC52 }\end{array}\right\} \quad \begin{aligned} & \text { In vitro recombi- } \\ & \text { IncP-1 } \\ & \text { Tra Ap } \mathrm{Km}^{\mathrm{s}} \mathrm{Tc}^{\mathrm{R}}\end{aligned} \begin{aligned} & \text { Hind of RP4 and } \\ & \text { of plasmid D }\end{aligned}$

This work

- $N$-methyl- $N^{\prime}$-nitro- $N$-nitrosoguanidine.

$\uparrow$ Plasmids were contained in $P$. mirabilis PM5006. Symbols designate resistance to: Ap, ampicillin; Cm, chloramphenicol; Km, kanamycin; Sm, streptomycin; Su, sulfonamide; Tc, tetracycline. Tra, transfer proficient.

\section{METHODS}

Bacterial strains and plasmids. These are listed in Table 1.

Plasmid isolation. This was done according to Prakash et al. (1981), as modified in this laboratory (Beck et al., 1982).

Media and antibiotics. These were as described by Beck et al. (1982) except that the minimal medium was not supplemented with methionine and calcium pantothenate.

Restriction analysis of plasmids. Plasmids were physically characterized by restriction fragmentation. Restriction endonucleaser EcoRI, HindIII, SmaI and PstI as well as T4 DNA ligase were obtained from Boehringer Mannheim. Reaction buffers for these were as recommended by the manufacturers. Double as well as some single digests were performed in a universal restriction buffer (Ruvkun \& Ausubel, 1981). Digests were electrophoresed according to McDonell et al. (1977), with buffer circulation. Gels usually contained $1 \mu \mathrm{g}$ ethidium bromide $\mathrm{ml}^{-1}$ and were frequently stained further in water or electrophoresis buffer containing $1 \mu \mathrm{g}$ ethidium bromide $\mathrm{ml}^{-1}$ followed by a brief de-staining rinse. Electrophoresis patterns were photographed on Polaroid 665 film under farUV illumination and negatives were densitometrically scanned with the scanning attachment of a Varian Cary 210 spectrophotometer. Nomenclature and molecular weights of R1drd 19 restriction fragments were determined according to Blohm \& Goebel (1978). Molecular weights of other fragments were calculated relative to these or the known vahues for RP4 restriction fragments (Depicker et al., 1977). Restriction fragments of preparative gel runs were eluted using the $\mathrm{NaClO}_{4}$-glass fibre filter technique of Chen \& Thomas (1980). Incubation of the filters in TE ( 1 mu-Tris, pH 8 plus 0.4 mu-EDTA) was extended to between $2 \mathrm{~h}$ and overnight at $4^{\circ} \mathrm{C}$ to obtain yields of about $80 \%$ after two or three washes.

Construction of RP4 recombinants. The single HindIII restriction site in the kanamycin resistance marker (Km) of plasmid RP4 (Barth \& Grinter, 1977) was utilized to construct and select recombinant clones of RP4 with specific HindIII fragments of plasmid D. In vitro ligation of $0.2 \mu \mathrm{g}$ of fragment with $0.2 \mu \mathrm{g}$ of HindIII-restricted RP4, transformation of $E$. coli $C 600 \mathrm{r}^{-} \mathrm{m}^{-}$with the ligated mixture and selection and purification of transformants were as described by Beck et al. (1982). The $\mathrm{Km}^{\mathrm{S}}$ clones were cultivated and plasmid DNA was 
extracted using the method of Clewell \& Helinski (1969). Inserted fragments were analysed for size and orientation by restriction fragmentation of the recombinant plasmids with HindIII, PstI and SmaI.

Plate matings. These were done as described previously (Beck et al., 1982; Coetzee, 1978). Briefly, recombinant plasmids were transferred by conjugation to PM5006 on Millipore membranes placed on NB2 agar. Transconjugants were selected by ampicillin $\left(30 \mu \mathrm{g} \mathrm{ml}^{-1}\right)$ on minimal media for donor counterselection. Screening for Cma was done by overnight matings of donors and auxotrophs (Table 1) on Hershey's agar. Recombinants were selected by replication to minimal media containing streptomycin $\left(1 \mathrm{mg} \mathrm{ml}^{-1}\right)$ and nalidixic acid $\left(75 \mu \mathrm{g} \mathrm{ml}^{-1}\right)$. In control experiments either donor or recipient was omitted.

\section{RESULTS}

\section{Restriction patterns of plasmids P-lac, D and Rldrd19}

Physical characterization of plasmid $D$ was performed by comparing its restriction pattern to those of the parental plasmids P-lac and R1drd19 (Fig. 1). HindIII fragments of plasmids P-lac and R1drd 19 (Fig. 1 a,c) had their equivalents in the patterns produced for plasmid D (Fig. $1 b$ ) except for P-lac fragment HindIII C (Fig. 1a) and Rldrd19 fragments HindIII A and D. This suggested that in the formation of plasmid $\mathrm{D}$, a region of $\mathrm{R} 1 d r d 19$, encompassing at least the HindIII B, C, E and F fragments, had been inserted within the HindIII C fragment of P-lac. In addition, two new HindIII fragments, noted as HindIII $\alpha$ and $\beta$ (Fig. $1 b$ ), which had no equivalent in either P-lac or R1drd19, emerged for plasmid D. These may represent the recombination regions between the two DNA molecules.

This analysis was carried further by digestion with $E c o$ RI which produced a more detailed pattern (Fig. $1 d, e, f$ ). The observed EcoRI pattern of R1drd19 (Fig. $1 f$ ) deviated in one respect
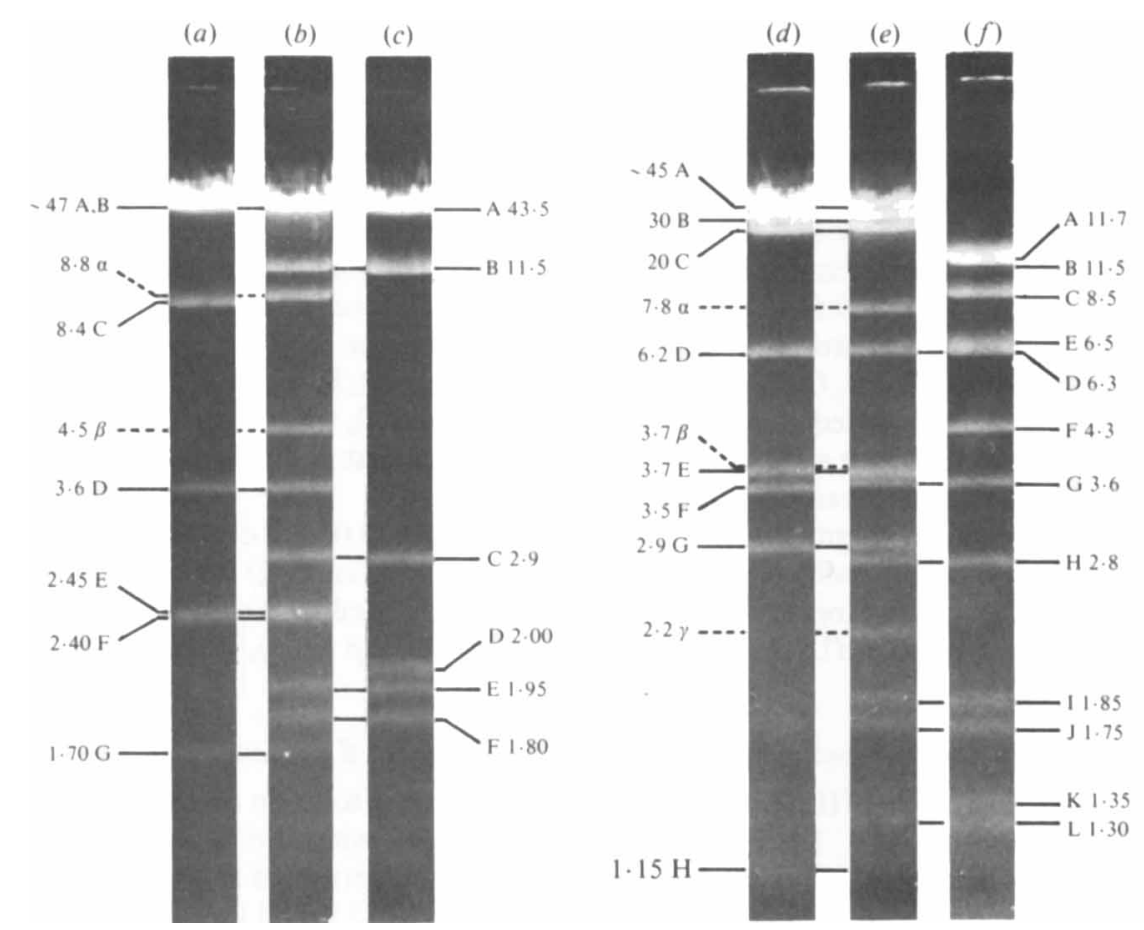

Fig. 1. Restriction patterns of plasmids P-lac $(a, d), \mathrm{D}(b, e)$ and $\mathrm{R} 1 d r d 19(c, f)$ for HindIII $(a, b, c)$ and $E c o R I(d, e, f)$. Nomenclature and molecular weights of $\mathrm{R} 1 d r d 19$ fragments are according to Blohm \& Goebel (1978) except for fragments HindIII A and EcoRI E (see text). Agarose gels of $0.4 \%$ (not shown) were used to resolve EcoRI D and E $(f)$, HindIII $\alpha$ and $C(a, b)$ and fragments >12 MDal. These facilitated establishment of indicated molecular weights. Fragments $<1.15$ MDal were observed on $2 \%$ agarose gels (not shown), in agreement with Blohm \& Goebel (1978). HindIII-restricted phage $\lambda$ (Philippsen et al., 1978) was used as molecular weight markers. 

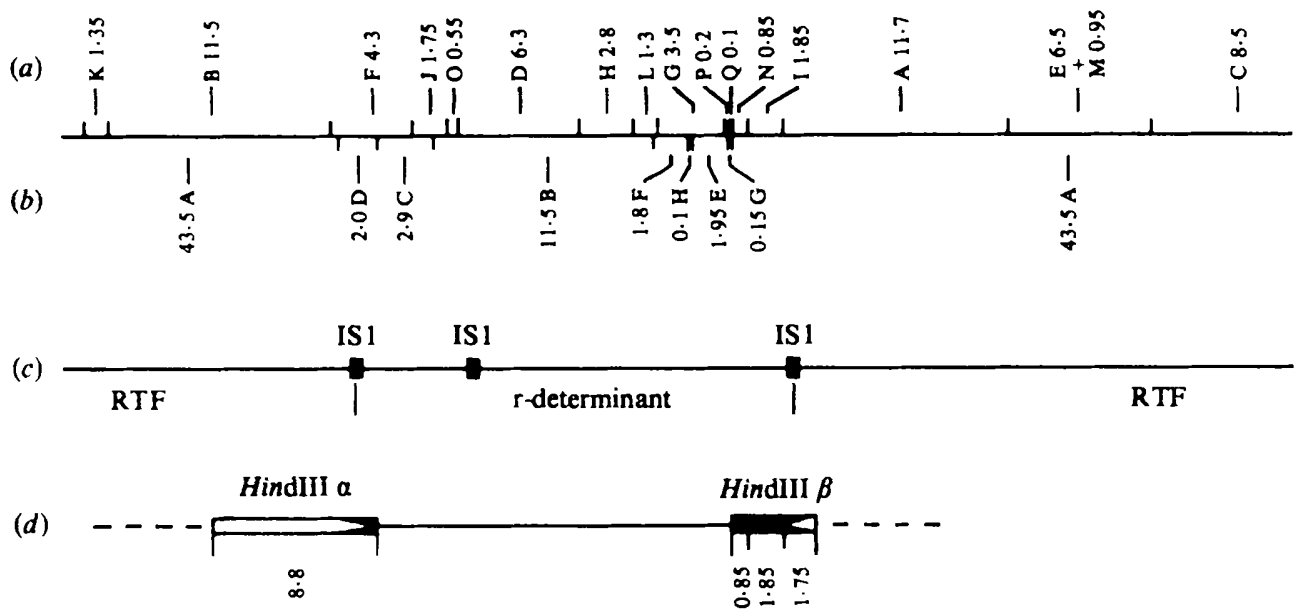

Fig. 2. (a) EcoRI and (b) HindIII restriction maps of R1drd19 (Clerget et al., 1981) amended with respect to size difference in EcoRI E and HindIII A (Fig. 1). (c) Location of r-det, RTF and IS1 sequences (Clerget et al., 1981) with respect to restriction maps. (d) Segment of plasmid D containing the r-det insert of RIdrd19 (see text). Recombination regions with P-lac DNA (broken line) on fragments $H$ indIII $\alpha$ and $\beta$ of plasmid $D$ are indicated (see text).

from that described by Blohm \& Goebel (1978). Fragment $E$ was found to be larger (6.5 MDal) than that observed before (5.1 MDal). This difference is not due to experimental conditions and was not further studied but may perhaps be attributed to a transposable element that had entered the plasmid. Consequently, revised restriction maps (Clerget et al., 1981) were amended (Fig. $2 a, b$ ) to accommodate this difference, and the molecular size of R1drd19 was taken as $63.9 \mathrm{MDal}$.

Figures $1(d, e$ and $)$ show that the EcoRI fragments of P-lac and R1drd19 (Fig. $1 d, f)$ had their equivalents in the pattern for $\mathrm{D}$ (Fig. $1 e$ ) with the exception of P-lac fragments EcoRI D and F (Fig. 1d) and RIdrd 19 fragments EcoRI A, B, C, E, F and $\mathrm{K}$ (Fig. $1 f$ ) as well as $\mathrm{M}$ (as visualized on a $2 \%, w / v$, agarose gel; not shown). Moreover, the only fragments common to $D$ and R1drd 19 were HindIII B, C, E and F (see above) and EcoRI, D, G, H, I, J and L (Fig. $1 e, f$ ) as well as $\mathrm{N}$ and $\mathrm{O}$ (as revealed on a $2 \%$ agarose gel; not shown), which stem from the $\mathrm{R} 1 d r d 19$ $r$-det (Clerget et al., 1981; see also Fig. $2 a, b$ ). This suggested that in the formation of plasmid D only the r-det of Rldrd19 was inserted into P-lac.

The lack of two EcoRI fragments of P-lac in the pattern for D (Fig. $1 d, e$ ) is curious and leads to the speculation that the insertion events in the formation of plasmid $D$ were complex and may have involved deletions and/or rearrangements. This is supported by the finding of three rather than two non-P-lac or R1drd19 fragments, noted as EcoRI $\alpha, \beta$ and $\gamma$, in the EcoRI digest of plasmid D (Fig. 1e).

\section{Restriction analysis of fragments HindIII $\alpha$ and $\beta$ of plusmid $D$}

$E c o$ RI restriction of $H$ indIII $\beta$ (4.5 MDal; Fig. $1 b$ ) gave rise to three fragments of $1.85,1.75$ and $0.85 \mathrm{MDal}$ (not shown). The first and last corresponded with $E c o$ RI fragments I and N, respectively, of R1drd19 (Fig. $2 a$ ). Hence, HindIII $\beta$ may be interpreted as containing the righthand terminal region of the R1drd19 r-det (Fig. $2 c, d$ ). The $1.75 \mathrm{MDal}$ fragment which had no equivalent in either P-lac or R1drd 19 would then contain the right-hand recombination region of these plasmids (Fig. $2 d$ ).

$H$ indIII $\alpha$ (Fig. 1 b) gave rise to four detectable EcoRI fragments of 3.7, 2.2, 1.2 and 0.9 MDal (not shown). The sum of the four fragments amounted to 8.0 MDal as compared to 8.8 MDal for $H$ indIII $\alpha$, suggesting that additional $E c o$ RI fragments (smaller than $0.6 \mathrm{MDal}$ ) must have been generated, which could not be visualized under the conditions of these experiments. The 
Table 2. Chromosome mobilization in Proteus mirabilis strain PM5006 by different plasmids

Values are from one of two independent but mutually consistent experiments. Map locations are from the circular chromosome map of Coetzee et al. (1982).

\begin{tabular}{|c|c|c|c|c|c|c|c|}
\hline \multirow[b]{3}{*}{ Donor } & \multicolumn{7}{|c|}{ No. of recombinants per $10^{8}$ donor cells } \\
\hline & his-1 & $\operatorname{trpA}$ & $i l v-2$ & pur-1 & cysC & metF & $\arg E$ \\
\hline & 7 & 21 & 32 & $\sim 32$ & 42 & 55 & 85 \\
\hline PM5006(RP4) & $<1$ & $<1$ & $<1$ & $<1$ & $<1$ & $<1$ & $<1$ \\
\hline PM5006(D) & $2 \times 10^{3}$ & 120 & 200 & 34 & 30 & 42 & 4 \\
\hline PM5006(pMC17) & $2 \times 10^{3}$ & 100 & 100 & 12 & 50 & 75 & $<1$ \\
\hline PM5006(pMC1) & 16 & $1.5 \times 10^{3}$ & 9 & 150 & $1.2 \times 10^{3}$ & $<1$ & $<1$ \\
\hline PM5006(pMC41) & $<1$ & $<1$ & $<1$ & $<1$ & $<1$ & $<1$ & $<1$ \\
\hline PM5006(pMC52) & $<1$ & $<1$ & $<1$ & $<1$ & $<1$ & $<1$ & $<1$ \\
\hline
\end{tabular}

2.2 MDal fragment corresponded to EcoRI $\gamma$ (Fig. $1 e$ ) of plasmid D, supporting the notion that HindIII $\alpha$ of plasmid D contains the other (left-hand) recombination region of P-lac and R1drd19. As no R1drd19 fragment was obtained from HindIII $\alpha$ the location of the left-hand recombination region could only be inferred in HindIII D of R1drd19 (Fig. 2b,d).

\section{Construction of RP4 recombinant plasmids}

Upon ligation of HindIII-restricted plasmid RP4 with purified HindIII fragments $\alpha$ and $\beta$ of plasmid D, approximately $5 \%$ (11 clones) of transformants for $H$ indIII $\alpha$ and $2.5 \%$ ( 27 clones) for HindIII $\beta$, were sensitive to kanamycin but resistant to ampicillin and tetracycline. This may suggest that the relevant fragments have been inserted into RP4.

\section{Physical characterization of $R P 4$ recombinant plasmids}

HindIII restriction of plasmid DNA from the 11 transformants for RP4:: $\alpha$ yielded fragment HindIII $\alpha$ in seven while four were not restricted. The latter was attributed to improper ligation leading to loss of both kanamycin resistance and the HindIII restriction site. Five of the seven plasmids containing HindIII $\alpha$ yielded non-RP4 fragments of 15.4 and 7.2 MDal when restricted with SmaI and two gave fragments of 20.2 and $2.4 \mathrm{MDal}$ (not shown), as compared with the known restriction patterns of RP4 (Depicker et al., 1977). This, together with the observation that SmaI cleaved HindIII $\alpha$ into fragments of 6.8 and 2.0 MDal (not shown), is consistent with the notion that the two populations of recombinants named pMC41 and pMC52, respectively, contained HindIII $\alpha$ in reverse orientation. Similarly, HindIII $\beta$, which gave fragments of $3 \cdot 2$ and 1.3 MDal when restricted with PstI (not shown), proved to be in reverse orientation in plasmids pMCl and pMC17 from the 27 clones obtained by transformation with RP4:: $\beta$.

\section{Transfer of recombinant plasmids to strain PM5006}

Transfer frequencies of plasmids pMC1, pMC17, pMC41 and pMC52 from E. coli $\mathrm{C} 600$ $\mathrm{r}^{-} \mathrm{m}^{-}$to $P$. mirabilis PM5006 by conjugation were $10^{-4}-10^{-3}$ per donor $\mathrm{h}^{-1} \cdot \mathrm{pMC41}$ and pMC52 rendered PM5006 Lac ${ }^{+}$, showing that HindIII $\alpha$ of plasmid D carried the essential genes of the P-lac lac operon.

\section{Chromosome mobilization in PM5006}

Transfer frequencies of various chromosomal markers for recombinant plasmids were compared with those for plasmids RP4 and D (Table 2). Since recipients were single auxotrophs, effects of strain variations can not be excluded and may explain slight modulation in transfer frequency gradients, e.g. for plasmid D (Table 2, line 2). These experiments (Table 2) indicate that only plasmids which contained the HindIII $\beta$ fragment of plasmid D could mobilize the PM5006 chromosome. Mobilization by pMC17 was indistinguishable from that of plasmid $D$, whereas that of pMCl (with HindIII $\beta$ in reverse orientation) was from two different origins (Table 2). This suggested that mobilization by plasmid $D$ could have been due to a new base sequence on HindIII $\beta$ as a result of recombination of P-lac and R1drd19 DNA. 


\section{DISCUSSION}

Insertion of one DNA molecule into another can be achieved by homologous recombination (Dressler \& Potter, 1982; Eisenstark, 1977) or by site-specific insertion events such as transposition (Kleckner, 1981; Starlinger, 1980) or chi-sequence-mediated recombination (Stahl, 1979). The present data showed that only the $\mathrm{r}$-det of R1drd19 was present in plasmid D. This together with the fact that the $r$-det is flanked by direct repeats of insertion sequence ISI (Clerget et al., 1981) favours a transposon-like insertion event of the R 1 drd $19 \mathrm{r}$-det into P-lac as a mechanism for the formation of plasmid $D$. This is supported by a number of findings. First, in transducing R1drd19 by Providence phage PL25 into Providence strain P29 (P-lac) no transductants were found with recombinant plasmids other than containing all antibiotic resistance markers of the RIdrd19 r-det (Coetzee, 1974). Second, stable variants of R1drd19 containing only the RTF and kanamycin marker, e.g. R1drd16 (Meynell \& Datta, 1967), or all but the kanamycin marker, e.g. pSC50 (Kopecko \& Cohen, 1975), or only the RTF (Cohen \& Miller, 1970; Silver \& Falkow, 1970) have been described. These structures may be interpreted in terms of the presence of IS1 copies on R1drd19, analogous to plasmid R100.1 (Hu et al., 1975; Ptashne \& Cohen, 1975) where ISl elements gave rise (Chandler et al., 1977; Hu et al., 1975) to poly-r-det R-factors, multimeric and monomeric autonomous r-dets and an autonomous RTF under different antibiotic selection pressure conditions (Perlman \& Rownd, 1975; Perlman et al., 1975; Rownd \& Mickel, 1971). Third, the packaging capacity of phage PL25 is 24.7 MDal of linear DNA (Van Rensburg, 1970) and is therefore capable of transducing a section of R1drd19 DNA containing the $23 \mathrm{MDal}$ r-det (Clerget $e t$ al., 1981). Further, if DNA rearrangements and/or deletions have occurred in the immediate vicinity of the recombination regions in plasmid D, as suggested by the complexity of the EcoRI restriction patterns of plasmid D and its HindIII $\alpha$ fragment, these could be attributed to similar IS1 activities (Kleckner, 1981; Kopecko, 1980; Nevers \& Saedler, 1978; Reif \& Saedler, 1977; Saedler, 1977; Starlinger \& Saedler, 1976; Starlinger, 1977, 1978), and correspondingly point towards a transposon-like insertion event of the r-det which was circularized by virtue of IS1 after being transduced by phage PL25.

Orientated, plasmid-mediated transfer of bacterial chromosome may result from interaction of homologous regions on plasmid and host chromosome (Pittard \& Adelburg, 1963). Whatever the nature of the homology, whether due to insertion of common sequences into both plasmid and chromosome (Dénarié et al., 1977; Grinter, 1981; Johnson \& Romig, 1979) or to production of R-prime plasmids (Barth, 1979; Beck et al., 1982; Juliot \& Boistard, 1979), the altered plasmids without exception exhibited $\mathrm{Cma}$, the extent and polarity of which corresponded to the extent and orientation of the homologous regions. The possibility that recombination of R1drd 19 with P-lac in the formation of plasmid D produced a region of homology with the PM5006 chromosome is unlikely on grounds of the fact that plasmids pMC1 and pMC17 with $H$ indIII $\beta$ in opposite orientation did not produce reversed mobilization trajectories. This may indicate that more than simple homology between plasmid D and the chromosome was involved, e.g. a new sequence on plasmid D fragment HindIII $\beta$ due to insertion and/or rearrangement events. Duplications in HindIII $\beta$ as a source of new sequences may be ruled out, since restriction mapping of $H$ indIII $\beta$ with 15 restriction enzymes did not reveal any duplicated segment (J. H. Hauman, this laboratory, unpublished results).

Possible roles for ISI and the chloramphenicol resistance marker which were identified (J. H. Hauman, unpublished results) on HindIII $\beta$ as well as for IS8, adjacent to the HindIII insertion site on RP4 (Depicker et al., 1980) are being investigated.

Professor J. N. Coetzee is thanked for providing bacterial strains and critical reading of the manuscript, Mrs Y. Beck for instructive assistance and criticism and Mr J. H. Hauman for making available unpublished data.

\section{REFER E NCES}

BArth, P. T. (1979). Plasmid RP4, with Escherichia coli DNA inserted in vitro, mediated chromosome transfer. Plasmid 2, 130-136.
BARTH, P. T. \& GRINTER, N. J. (1977). Map of plasmid RP4 derived by insertion of transposon C. Journal of Molecular Biology 113, 455-474. 
BeCK, Y., COETZEe, W. F. \& COETZEe, J. N. (1982). In vitro constructed RP4-prime plasmids mediate orientated mobilization of the Proteus morganii chromosome. Journal of General Microbiology 128, 11631169.

BLOHM, D. \& GoEBEL, W. (1978). Restriction map of the antibiotic resistance plasmid R1drd-19 and its derivatives pKN102 (R1drd-19B2) and R1drd-16 for the enzymes BamHI, HindIII, EcoRI and Sall. Molecular and General Genetics 167, 119-127.

Chandler, M., Silver, L., Frey, J. \& Caro, L. (1977). Suppression of an Escherichia coli dnaA mutation by the integrated R-factor R100.1:generation of small plasmids after integration. Journal of Bacteriology 130, 303-311.

Chen, C. W. \& Thomas, C. A. (1980). Recovery of DNA segments from agarose gels. Analytical Biochemistry 101, 339-341.

Clerget, M., Chandler, M. \& Caro, L. (1981). The structure of R1drd19: a revised physical map of the plasmid. Molecular and General Genetics 181, 183191.

Clewell, D. B. \& HelinsKi, D. R. (1969). Supercoiled circular DNA-protein complex in Escherichia coli: purification and induced conversion to an open circular DNA form. Proceedings of the National Academy of Sciences of the United States of America 62, 1159-1166.

CoztzeE, J. N. (1974). Properties of Proteus and Providence strains harbouring recombinant plasmids between P-lac, R1drd19 or R447b. Journal of General Microbiology 80, 119-130.

Coetzee, J. N. (1975). Chromosome transfer in Proteus mirabilis mediated by a hybrid plasmid. Journal of General Microbiology 86, 133-146.

COETZEE, J. N. (1978). Extension of a chromosome linkage group of Proteus mirabilis. Journal of General Microbiology 107, 155-163.

Coetzee, J. N., JACOB, A. E. \& Hedges, R. W. (1975). Susceptibility of a hybrid plasmid to excision of genetic material. Molecular and General Genetics 140 , 7-14.

Coetzee, J. N., van Dijken, M. C. \& Coetzee, W. F. (1982). Proteus mirabilis. In Genetic Maps Vol. II, pp. 152-157. Edited by S. J. O'Brien. Bethesda, Maryland: National Cancer Institute, National Institutes of Health.

Cohen, S. N. \& Miller, C. A. (1970). Nonchromosomal antibiotic resistance in bacteria. III. Isolation of the discrete transfer unit of the R-factor R1. Proceedings of the National Academy of Sciences of the United States of America 67, 510-516.

Datta, N., Hedges, R. W., Shaw, E. J., Sykes, R. B. \& Richmond, M. H. (1971). Properties of an Rfactor from Pseudomonas aeruginosa. Journal of Bacteriology 108, 1244-1249.

DÉnARIÉ, J., Rosenberg, C., Bergeron, B., Boucher, C., Michel, M. \& Barate de Bertalmo, M. (1977). Potential of RP4::Mu plasmids for in vivo genetic engineering of Gram-negative bacteria. In $D N A$ Insertion Elements, Plasmids and Episomes, pp. 507 520. Edited by A. I. Bukhari, J. A. Shapiro \& S. L. Adhya. Cold Spring Harbor, New York: Cold Spring Harbor Laboratory.

DePICKER, A., VAN MONTAGU, M. \& SCHELl, J. (1977). Physical map of RP4. In DNA Insertion Elements,
Plasmids and Episomes, pp. 678-679. Edited by A. I. Bukhari, J. A. Shapiro \& S. L. Adhya. Cold Spring Harbor, New York: Cold Spring Harbor Laboratory.

DEPICKER, A., DE Block, M., INZE, D., VAN MoNTAGU, M. \& SCHELL, J. (1980). IS-like element IS8 in RP4 plasmid and its involvement in cointegration. Gene 10, 329-338.

DREssleR, D. \& POTTER, H. (1982). Molecular mechanisms in genetic recombination. Annual Review of Biochemistry 51, 727-761.

EISENSTARK, A. (1977). Genetic recombination in bacteria. Annual Review of Genetics 11, 369-396.

Falkow, S., Wohlhiteter, J. A., Citarella, R. V. \& BARON, L. S. (1964). Transfer of episomic elements to Proteus. II. Nature of $\mathrm{lac}^{+}$Proteus strains isolated from clinical specimens. Journal of Bacteriology 88, 1598-1601.

GrINTER, N. J. (1981). Analysis of chromosome mobilization using hybrids between plasmid RP4 and a fragment of bacteriophage $\lambda$ carrying IS1. Plasmid 5, 267-276.

HeDGes, R. W. (1975). R factors from Proteus mirabilis and $P$. vulgaris. Journal of General Microbiology 87, 301-311.

Holloway, B. W. \& Richmond, M. H. (1973). R factors used for genetic studies in strains of Pseudomonas aeruginosa and their origin. Genetical Research 21, 103-105.

Hu, S., Ohtsubo, E., Davidson, N. \& Saedler, H. (1975). Electron microscope heteroduplex studies of sequence relations among bacterial plasmids : identification and mapping of the insertion sequences IS1 and IS2 in F and R plasmids. Journal of Bacteriology 122, 746-755.

Johnson, S. R. \& Romig, W. R. (1979). Transposonfacilitated recombination in Vibrio cholerae. Molecular and General Genetics 170, 93-101.

Juliot, J. S. \& BoISTARD, P. (1979). Use of RP4-prime plasmids constructed in vitro to promote a polarized transfer of the chromosome in Escherichia coli and Rhizobium meliloti. Molecular and General Genetics 173, 289-298.

KLECKNER, N. (1981). Transposable elements in prokaryotes. Annual Review of Genetics 15, 341404.

KOPECKO, D. J. (1980). Specialized genetic recombination systems in bacteria: their involvement in gene expression and evolution. Progress in Molecular and Subcellular Biology 7, 135-234.

KOPECKO, D. J. \& COHEN, S. N. (1975). Site-specific $r e c A$-independent recombination between bacterial plasmids: involvement of palindromes at the recombinational loci. Proceedings of the National Academy of Sciences of the United States of America 72, 13731377.

McDonell, M. W., Simon, M. N. \& Studier, F. W. (1977). Analysis of restriction fragments of T7 DNA and determination of molecular weights by electrophoresis in neutral and alkaline gels. Journal of Molecular Biology 110, 119-146.

Meynell, E. \& DatTA, N. (1967). Mutant drug resistance factors of high transmissibility. Nature, London 214, 885-887.

Nevers, R. \& SAedler, H. (1978). Mapping and characterization of an $E$. coli mutant defective in 
IS1-mediated deletion formation. Molecular and General Genetics 160, $209-214$.

Pearce, L. E. \& Mrynell, E. (1968). Specific chromosomal affinity of a resistance factor. Joumal of General Micnobiology 50, 159-172.

Perluan, D. \& Rownd, R. H. (1975). Transition of R factor NR1 in Proteus mirabilis: molecular structure and replication of NR1 deoxyribonucleic acid. Journal of Bacterialogy 123, 1013-1034.

Perluna, D., Twose, T. M., Holland, M. J. \& RowND, R. H. (1975). Denaturation mapping of $\mathbf{R}$ factor deoxyribonucleic acid. Joumal of Bacteriology 123, 1035-1042.

Phulippsen, P., Krayer, R. A. \& DAVts, R. W. (1978). Cloning of the yeast ribosomal DNA repeat unit in SstI and $H$ indIII lambda vectors using genetic and physical size selections. Jowmal of Molecular Biology 123, 371-386.

Pittakd, A. J. A Adalburg, E. A. (1963). Gene transfer by $F^{\prime}$ strains of Escherichia coli K12. II. Interaction between F-merogenote and chromosome during transfer. Joumal of Bacteriology 85, 14021408.

Praxash, R. K., Schmprroort, R. A. \& Nutr, M. P. (1981). Large plasmids of fast-growing rhizobia: homology studies and location of structural nitrogen fixation (nif) genes. Joumal of Bacteriology 145, 1129-1136.

Ptashine, K. \& Cotren, S. N. (1975). Occurrence of insertion sequence (IS) regions on plasmid deoxyribonucleic acid as direct and inverted nucleotide sequence duplications. Joumal of Bacteriology 122 , 776-781.

Relf, H.-J. \& Sadler, H. (1977). Chromosomal rearrangements in the gal region of $E$. coli $\mathrm{K} 12$ after integration of IS1. In DNA Insertion Elements, Plasmids and Episomes, pp. 81-91. Edited by A. I. Bukhari, J. A. Shapiro \& S. L. Adhya. Cold Spring Harbor, New York: Cold Spring Harbor Laboratory.
Rownd, R. \& Mickel, S. (1971). Dissociation and reassociation of RTF and r-determinants of $R$ factor NR1 in Proteus mirabilis. Nature New Biology 234, 40-43.

Ruviun, G. B. \& Ausubel, F. M. (1981). A general method for site-directed mutagenesis in procaryotes. Nature, London 209, 85-88.

SAEDLER, H. (1977). IS1 and IS2 in E. coli: Implications for the evolution of the chromosome and some plasmids. In DNA Insertion Elements, Plasmids and Episomes, pp. 65-72. Edited by A. I. Bukhari, J. A. Shapiro \& S. L. Adhya. Cold Spring Harbor, New York: Cold Spring Harbor Laboratory.

Silver, R. P. \& FAlKow, S. (1970). Studies on resistance transfer factor deoxyribonucleic acid in Escherichia coli. Joumal of Bacteriology 104, 340-344.

StAkI, F. W. (1979). Special sites in generalized recombination. Anurual Review of Genetics 13, 7-24.

StARLINGER, P. (1977). DNA rearrangements in procaryotes. Annual Review in Genetics 11, 103-126.

StaRLINGER, P. (1978). In vivo formation of recombinant DNA molecules by IS-elements and transposons. In Genetic Engineering, pp. 123-143. Edited by A. M. Chakrabarty. West Palm Beach, Florida: C.R.C. Press.

Starlinger, P. (1980). IS-elements and transposons. Plasmid 3, 241-259.

Starlinger, P. \& SAEDLER, H. (1976). IS-elements in microorganisms. Current Topics in Microbiology and Immunology 75, 111-152.

Van Rensburg, A. J. (1970). Studies on Proteus and Providence spheroplasts, 1-forms and bacteriophage mucleic acids. M.D. thesis, University of Pretoria, Republic of South Africa.

WoHLhIBter, J. A., Falrow, S., Citarklla, R. V. \& BARON, L. S. (1964). Characterization of DNA from a Proteus strain harboring an episome. Joumal of Molecular Biology 9, 576-588. 